\title{
Identification of humpback whale Megaptera novaeangliae wintering habitat in the Northwestern Hawaiian Islands using spatial habitat modeling
}

\author{
D. W. Johnston ${ }^{1,2, *}$, M. E. Chapla ${ }^{1}$, L. E. Williams ${ }^{2}$, D. K. Mattila ${ }^{3}$ \\ ${ }^{1}$ Joint Institute for Marine and Atmospheric Research, University of Hawai'i at Manoa, 1000 Pope Road, \\ Marine Science Building 312, Honolulu, Hawai'i 96822, USA \\ ${ }^{2}$ Duke University Marine Laboratory, 135 Duke Marine Lab Rd., Beaufort, North Carolina 28516, USA \\ ${ }^{3}$ Hawaiian Islands Humpback Whale National Marine Sanctuary, 726 South Kihei Road, Kihei, Hawai'i 96753, USA
}

\begin{abstract}
During the winter months, humpback whales Megaptera novaeangliae prefer warm and shallow regions, and these habitat preferences have been linked to reproductive status and success. Central North Pacific humpback whales winter in the main Hawaiian Islands (MHI), with peak densities occurring in late March. The Hawaiian Archipelago extends over $1800 \mathrm{~km}$ to the northwest of the MHI and includes a number of islands and atolls referred to as the Northwestern Hawaiian Islands (NWHI). The NWHI likely provide wintering habitat for humpbacks in the North Pacific, but have rarely been surveyed during winter. We modeled the extent and spatial location of humpback wintering habitat across the Hawaiian Archipelago, using General Bathymetric Chart of the Ocean (GEBCO) 1 min bathymetry data and synoptic and January-March averaged sea surface temperature (SST) grids (advanced very high resolution radiometer AVHRR) according to previously published habitat envelopes. Using these data, we produced polygons identifying areas shallower than $200 \mathrm{~m}$ and warmer than $21.1^{\circ} \mathrm{C}$ as potential wintering habitat. We then compared these habitat estimates with the locations of visual and acoustic detections of humpbacks during a March 2007 pilot survey across the NWHI. The spatial analysis predicted approximately $21900 \mathrm{~km}^{2}$ of wintering habitat in the Hawaiian Archipelago, with $2 / 3\left(14700 \mathrm{~km}^{2}\right)$ occurring in the NWHI. Nine sightings of humpback whales $(\mathrm{n}=19)$ occurred during the $15 \mathrm{~d}$ cruise, including 3 groups with small calves or exhibiting breeding behaviors. All sightings occurred in warm, shallow water at or within our predicted habitat regions. Acoustic detections of humpbacks followed the same pattern. The results of our habitat analysis and survey observations document for the first time the existence of extensive wintering habitat used by humpback whales in the NWHI. These novel but simple methods are applicable for predicting wintering locations of humpbacks in other regions, and our results should be incorporated into assessment and recovery efforts for humpback whales in the North Pacific.
\end{abstract}

KEY WORDS: Humpback whale $\cdot$ Wintering habitat $\cdot$ Northwestern Hawaiian Islands · Spatial modeling Resale or republication not permitted without written consent of the publisher

\section{INTRODUCTION}

Humpback whales Megaptera novaeangliae are large mysticete whales known to forage at high latitudes during summer months and subsequently migrate extensive distances to breed in lower latitudes during the winter months (Chittleborough 1965,
Dawbin 1966, Baker et al. 1986, Katona \& Beard 1990, Clapham \& Mead 1999). During the winter breeding season, they appear to prefer warm and shallow waters throughout their range (Whitehead \& Moore 1982, Katona \& Beard 1990, Clapham \& Mead 1999, Ersts \& Rosenbaum 2003, Rasmussen et al. 2007). The distribution of humpbacks within shallow 
water areas may be linked to social organization (Ersts \& Rosenbaum 2003) and the reproductive status of animals - and in some cases their reproductive success (Craig \& Herman 2000). Various studies have documented the behavior and distribution of humpbacks in the main Hawaiian Islands (MHI) during the breeding season from the 1970s onward (Herman \& Antinoja 1977, Shallenberger 1977, Mobley et al. 1999, Craig \& Herman 2000). The habitat envelope previously described for humpbacks wintering in Hawai'i (see Rice \& Wolman 1982) indicates they are most frequently found in waters less than $200 \mathrm{~m}$ deep, at temperatures ranging from 24 to $28^{\circ} \mathrm{C}$ and a latitude of between 19 and $22^{\circ} \mathrm{N}$ (Dawbin 1966, Herman \& Antinoja 1977, Herman 1979, Mobley et al. 1999). Recently, Rasmussen et al. (2007) expanded this envelope by establishing $21.1^{\circ} \mathrm{C}$ as the worldwide lower temperature limit for wintering humpbacks and suggested that wintering habitat is related to temperature, irrespective of latitude. The authors based their conclusions on a meta-analysis of satellite-derived, long-term mean sea surface temperature (SST) data (for the month of peak humpback occurrence) for each wintering area worldwide, as indicated in the published literature (Rasmussen et al. 2007; see their supplementary data for a description of studies included in their analysis). Wintering areas were considered those where small calves were present and where adults displayed breeding behaviors (e.g. competitive groups, singing).

Humpbacks in the North Pacific were greatly reduced by commercial whaling, which began there in 1889 (Johnson \& Wolman 1984). The estimated population size, prior to 1905, was at least 15000 whales (Rice 1978). The population was reduced to between 1000 and 1200 individuals by 1965, when the International Whaling Commission (IWC) banned the commercial killing of humpbacks (Rice 1978, Johnson \& Wolman 1984, Perry et al. 1999). In 1973, humpback whales were listed as endangered in US waters under the US Endangered Species Act, and a recovery plan for this species was first introduced in 1991 (NMFS 1991, Perry et al. 1999).

Historical evidence suggests that humpback whales did not utilize habitat surrounding the main Hawaiian Islands until approximately $200 \mathrm{yr}$ ago (Herman 1979). They were not included in the whaling records from the area, and there does not appear to be a specific word in the Hawaiian language for humpback whale (Herman 1979). The first estimates of the Hawaiian humpback population were made in the late 1970s and ranged from 250 to 600 individuals (Herman \& Antinoja 1977, Shallenberger 1977, Wolman \& Jurasz 1977). The most recent population estimate for humpback whales in Hawai'i is 4005 with a coefficient of variation $(\mathrm{CV})=0.096$ (Calambokidis et al. 1997), and humpback whales in the central North Pacific appear to have increased at $10 \% \mathrm{yr}^{-1}$ from 1979 through 1996 (Mizroch et al. 2004). Data generated from aerial surveys conducted throughout the MHI during 1993, 1995, 1998, and 2000 suggest that the density of whales may be increasing in this area by about $7 \% \mathrm{yr}^{-1}$ (Mobley et al. 2001).

The Hawaiian Archipelago actually extends over $1800 \mathrm{~km}$ to the northwest of the MHI and includes a number of islands, atolls and seamounts that likely provide somewhat similar habitats for wintering humpback whales in the Pacific. This region is referred to as the Northwestern Hawaiian Islands (NWHI), and all terrestrial habitats and marine habitats along the chain and within approximately $100 \mathrm{~km}$ of its east/west axis have recently been established as the Papahānaumokuākea Marine National Monument, which provides further protection for marine and terrestrial species found within its borders. Surveys for cetaceans in the NWHI, especially during winter, are extremely limited. The only quantitative cetacean survey for Hawaiian waters (Barlow 2006) was conducted largely outside the humpback whale breeding season. Visual and acoustic survey effort across the entire Hawai'i exclusive economic zone (EEZ) (including the NWHI) during July through November 2002 detected only one humpback whale, just north of the Big Island of Hawai'i in the MHI (Barlow 2006). No humpbacks were detected in the NWHI portions of this survey, suggesting that humpbacks are only present in this region during the winter/spring months (Barlow 2006). Cetacean survey efforts previous to this 2002 survey are almost completely lacking for the NWHI, with the exception of minimal ship-based and aerial survey efforts in the late 1970s (Herman \& Antinoja 1977) and extensive spinner dolphin research conducted largely within the lagoons of atolls (Karczmarski et al. 2005). Based on the 1970s survey data, Herman (1979) concluded that 'there is no evidence of current habitation by the whales [humpbacks] in the northwest Hawaiian Islands, though a few 'strays' may be encountered there.' In addition, Herman et al. (1980) found no evidence of any significant migration through the NWHI.

The purpose of the present paper is to predict the locations and area of potential humpback whale wintering habitat in the Hawaiian Archipelago through a spatial analysis of bathymetric and satellite-derived SST data and then to compare these findings with visual and acoustic observations of humpbacks made during a pilot study in the NWHI during the 2006-2007 breeding season. 


\section{MATERIALS AND METHODS}

Study area and survey platform. The Hawaiian Archipelago is a chain of islands and coral atolls of volcanic origin that spans more than $2000 \mathrm{~km}$ in the central North Pacific (Fig. 1). From March 26 through April 12 2007, cetacean observations were collected from a 68 m T-AGOS Class oceanographic vessel (NOAA RV 'Oscar Elton Sette') during a cruise across the NWHI chain. The cruise originated and ended in Honolulu, $\mathrm{HI}$, with the westernmost excursion of the survey proximate to Midway Atoll.

Visual and acoustic surveys. Visual surveys were conducted from the flying bridge with $25 \times 150$ 'big eye' binoculars. Two observers (port and starboard) scanned constantly from straight ahead to $90^{\circ}$ abeam during daylight hours along preset tracklines across the NWHI. Due to time restrictions, a systematic-randomized survey design (an important component to produce unbiased survey results; see Buckland et al. 2001) of the study region could not be employed. Tracklines for this pilot study were instead designed to allow for survey effort at several islands and atolls in the chain during daylight hours, usually following the
$183 \mathrm{~m}$ (100 fathom) isobath at atolls and banks, as well as several open ocean tracks to optimize sampling efficiency during the cruise (Fig. 1). Observations were conducted following standard distance sampling/line transect field methods for cetaceans (Buckland et al. 2001), similar to those employed in Barlow (2006). During ship surveys, the location, species present, general behavior and group size estimates for each cetacean encounter were recorded, and sightings data were imported into ArcGIS 9.1 for further spatial analysis. Whenever possible, biopsy samples and digital photographs of encountered cetaceans were obtained for genetic studies, species identification confirmations and individual photo-identification. Photographs were obtained with Canon digital single lens reflexes (SLRs) equipped with 100 to $300 \mathrm{~mm}$ zoom lenses. Photographs were shot in 24-bit color at a resolution of 3072 $\times 2048$ pixels and saved in jpg format. Skin/blubber biopsies were obtained from individuals using a Barnett RX-150 crossbow and Ceta-Dart darts with sterile stainless steel tips. Biopsy samples were kept on ice and frozen in liquid nitrogen at the end of each day.

Simultaneous acoustic observations were also conducted using a towed hydrophone array. The towed

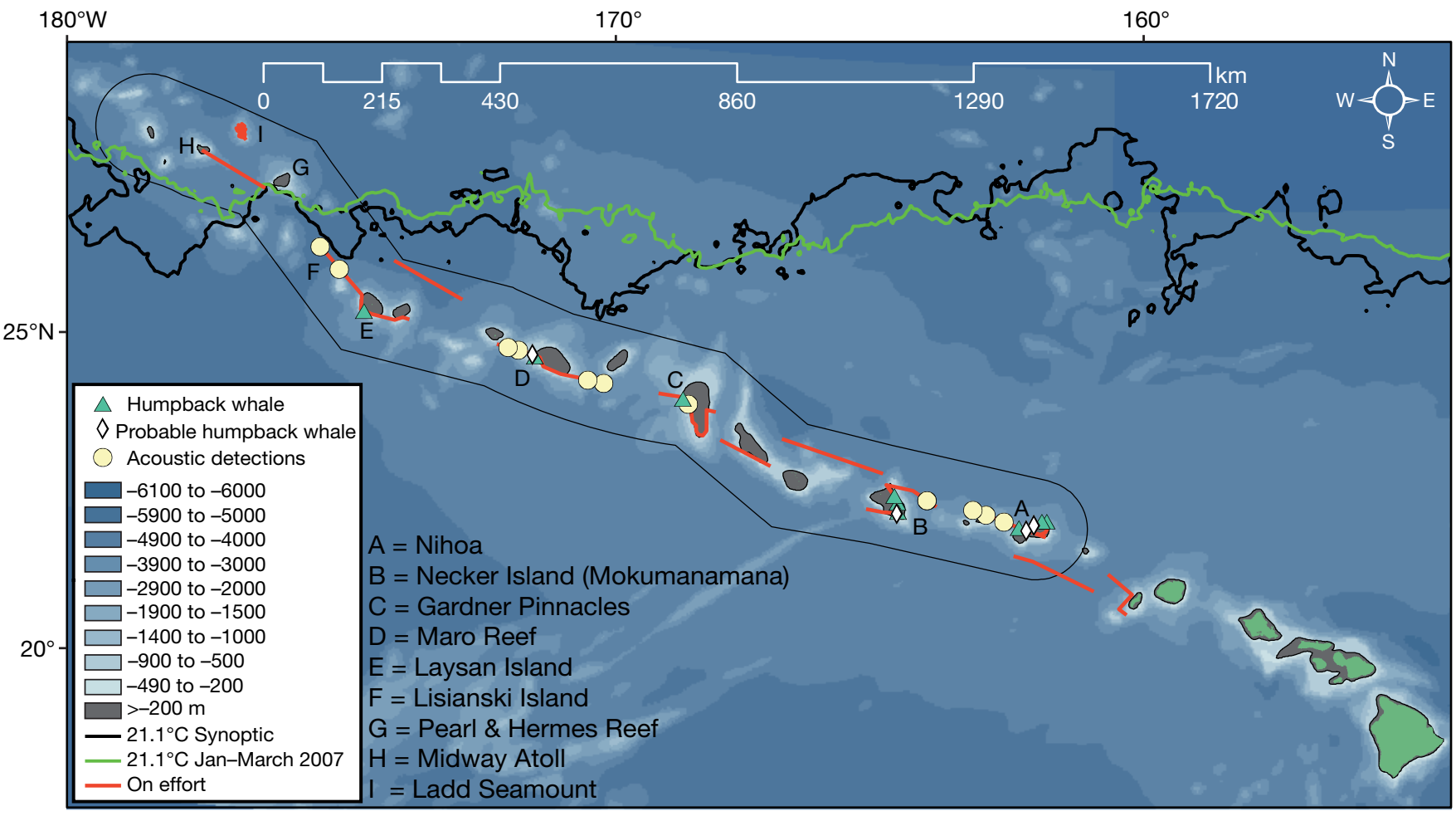

Fig. 1. Map of the Hawaiian Archipelago detailing the bathymetry, $200 \mathrm{~m}$ shallow regions (grey), humpback whale Megaptera novaeangliae and probable humpback whale sightings, humpback whale acoustic detections, synoptic and spring-2007 $21.1^{\circ} \mathrm{C}$ sea surface temperature (SST) contours and the boundary of the Papahānaumokuākea Marine National Monument during March-April 2007. Bathymetry derived from General Bathymetric Chart of the Ocean (GEBCO) 1 min world bathymetric dataset; SST contours derived from averaged SST data (NOAA-AVHRR GAC sensor) gridded at $0.1^{\circ}$ resolution/pixel. Monument boundary: thin black line 
array (Seiche Instruments) consisted of 4 hydrophone elements with linear sensitivity to frequencies between 1 and $100 \mathrm{kHz}$. The array was towed approximately $150 \mathrm{~m}$ behind the ship, and acoustic signals were transmitted up the cable to an analog to digital converter/mixer sampling at $192 \mathrm{kHz}$. These signals were then split between a hard disk recording system sampling at $96 \mathrm{kHz}$ and 2 personal laptop computers fitted with software for real-time visualization/recording (Ishmael 1.0) and spatial localization (WhalTrak 2.0) of cetacean sounds. Acoustic detections of humpbacks were noted, and the locations of these detections were imported into ArcGIS 9.1 for comparisons with visual detections and habitat data.

Spatial analysis. We assessed the extent of potential wintering habitat in the Hawaiian Archipelago through a combined analysis of bathymetric and synoptic satellite-derived SST data consistent with previous studies on humpback breeding habitat (Mobley et al. 1999, Craig \& Herman 2000, Rasmussen et al. 2007). Initially, we calculated the area of shallow water regions $(<200 \mathrm{~m}$ depth) as determined from a sub-sample $\left(180^{\circ} \mathrm{W}, 31^{\circ} \mathrm{N} ; 154^{\circ} \mathrm{W}, 18^{\circ} \mathrm{N}\right)$ of the General Bathymetric Chart of the Ocean (GEBCO) 1 min worldwide bathymetry dataset. GEBCO gridded bathymetric data were imported into ArcGIS 9.1, plotted with a Mercator projection, and $200 \mathrm{~m}$ contours were created using the Spatial Analyst extension. These contours were then converted to polygons and the area of each polygon calculated to provide a total amount of shallow habitat in the archipelago. Synoptic weekly averaged SST data (NOAA-AVHRR [advanced very high resolution radiometer] GAC [global area coverage] sensor) for the same region were obtained from the NOAA OceanWatch Central Pacific Node and were imported into ArcGIS and gridded (0.1 degree resolution/pixel). Average SST data (as above) for January through March were also obtained and imported into the GIS. Contours of SST at $0.1^{\circ} \mathrm{C}$ were created as above and both the synoptic and average $21.1^{\circ} \mathrm{C}$ contour plotted (Fig. 1). The $21.1^{\circ} \mathrm{C}$ SST contour was chosen as it appears to be the lower limit of temperature preference for breeding humpbacks worldwide (Rasmussen et al. 2007).

To compare our study region with the known wintering habitat of humpback whales in Hawai'i, we then partitioned the Hawaiian Archipelago into 2 regions within the GIS database: the main Hawaiian Islands consisting of all the area east of $160.75^{\circ} \mathrm{W}$, and the Northwestern Hawaiian Islands to the west of this line. Island areas were then subtracted from $200 \mathrm{~m}$ contour polygons and the remaining areas summed to estimate the amount of shallow habitat in each section. Only shallow areas within the $21.1^{\circ} \mathrm{C}$ SST contours were included in the analysis.

\section{RESULTS}

\section{Survey effort}

Approximately $1690 \mathrm{~km}$ of trackline were surveyed during $12 \mathrm{~d}$ of visual observations, with only $2 \mathrm{~d}$ of inclement weather ( $>22$ knots of sustained winds and Beaufort 5+) when surveys were not conducted. The path of the ship during on-effort periods over the entire cruise is illustrated in Fig. 1. The amount of survey effort broken down by depth and sea surface temperature is presented in Table 1.

\section{Visual and acoustic observations}

During this cruise 9 groups of humpbacks were detected visually and confirmed through photodocumentation (Fig. 1). In addition, 4 encounters of large whales were recorded as probable humpback whales, but due to time restrictions we could not deviate from the track line to fully confirm the species identification (i.e. no photos collected). These unconfirmed sightings are plotted in Fig. 1 as probable humpback whales and all occurred in shallow water proximate to confirmed humpback whale sightings. The best estimate of confirmed humpbacks detected was approximately 24 individuals, and at least 5 probable humpback whales were sighted. Group size estimates and group composition are presented in Table 2. At least 2 groups had young calves present. Three groups were enganged in competitive group behaviours that are shown by breeding whales in the main Hawaiian Islands (Baker \& Herman 1984). Humpbacks were detected at the shallow banks surrounding Nihoa Island (Fig. 1; A), Necker Island (Mokumanamana: Fig. 1; B), Gardner Pinnacles (Fig. 1; C), Maro Reef (Fig. 1; D) and Lisianski Island (Fig. 1; E). During these encounters, we obtained 662 photos of humpbacks (from which 2 distinct flukes and 4 distinct dorsal fin/body scar patterns were obtained for identification purposes) and 2 biopsies of humpbacks at Necker Island. Preliminary fluke matches indicate that one whale that wintered in the MHI during 2006 was present in the NWHI during winter 2007. No humpbacks were detected visually or acoustically over the shallow portions

Table 1. Visual survey effort $(\mathrm{km})$ allocation by depth (shallow: $<200 \mathrm{~m}$, deep: $>200 \mathrm{~m}$ ) and sea surface temperature (cool: $<21.1^{\circ} \mathrm{C}$, warm: $>21.1^{\circ} \mathrm{C}$ ) during March-April 2007 in the Northwestern Hawaiian Islands

\begin{tabular}{|lcccc|}
\hline & $\begin{array}{c}\text { Deep, } \\
\text { warm }\end{array}$ & $\begin{array}{c}\text { Shallow, } \\
\text { warm }\end{array}$ & $\begin{array}{c}\text { Deep, } \\
\text { cool }\end{array}$ & $\begin{array}{c}\text { Shallow, } \\
\text { cool }\end{array}$ \\
\hline Survey effort $(\mathrm{km})$ & 721 & 688 & 165 & 116 \\
\hline
\end{tabular}


Table 2. Megaptera novaeangliae. Groups size and composition for confirmed and probable humpback whale sightings during March-April 2007 in the Northwestern Hawaiian Islands. UN: unknown

\begin{tabular}{|c|c|c|c|c|}
\hline Date $(\mathrm{mo} / \mathrm{d})$ & Species & Best estimate & No. of calves & Group composition \\
\hline $03 / 30$ & Humpback whale & 1 & 0 & Individual \\
\hline $03 / 30$ & Humpback whale & 5 & 1 & Mother/Calf/Escorts \\
\hline $03 / 30$ & Humpback whale & 3 & UN & Competitive group \\
\hline $04 / 06$ & Humpback whale & 1 & 0 & Individual \\
\hline $04 / 07$ & Humpback whale & 1 & 0 & Individual \\
\hline $04 / 08$ & Humpback whale & 2 & UN & UN \\
\hline $04 / 10$ & Humpback whale & 4 & 1 & Mother/Calf/Escorts \\
\hline $04 / 10$ & Humpback whale & 1 & 0 & Individual \\
\hline $04 / 10$ & Humpback whale & 1 & 0 & Individual \\
\hline $03 / 29$ & Probable humpback whale & 1 & 0 & Individual \\
\hline $03 / 29$ & Probable humpback whale & 1 & 0 & Individual \\
\hline $03 / 30$ & Probable humpback whale & 1 & UN & UN \\
\hline $04 / 03$ & Probable humpback whale & 1 & UN & UN \\
\hline $04 / 07$ & Probable humpback whale & 1 & UN & UN \\
\hline
\end{tabular}

of Ladd Seamount, located centrally between Midway Atoll and Pearl and Hermes Reef and just slightly north of both atolls, despite significant survey efforts during bottom mapping for the deployment of a bottommounted acoustic recorder.

The array was towed during daylight hours and during one night of surveys at Ladd Seamount. The spatial locations where humpback whale 'song' components were clearly audible above background noise or where acoustic detections were corroborated by a concurrent visual observation are plotted in Fig. 1. In situations where multiple loud calls were detected over a period of $1 \mathrm{~h}$ or more, the spatial location of the mid-point time in the detection period was plotted on the map. We detected humpbacks acoustically on 6 of 12 survey days, 5 of which were in the NWHI. We detected humpback whale calls proximate to Nihoa Island (Fig. 1; A) and across the shallow banks west of Nihoa and between Nihoa and Necker Islands. We detected humpbacks acoustically at Gardner Pinnacles, to the west of Maro Reef and during the approach to Laysan Island, as well as north and east of 2 small shallow banks between Lisianski Island and Pearl and Hermes Reef, an area which our survey trackline did not traverse (Fig. 1; F).

\section{Potential wintering habitat available to humpback whales}

The results of the spatial analysis are presented in Fig. 1. The predicted total area with depths shallower than $200 \mathrm{~m}$ in the Northwestern Hawaiian Islands and in waters warmer than $21.1^{\circ} \mathrm{C}$ is approximately $14700 \mathrm{~km}^{2}$. In contrast, the predicted total area with depths shallower than $200 \mathrm{~m}$ in the main Hawaiian Islands is approximately $7200 \mathrm{~km}^{2}$.

\section{DISCUSSION}

Our pilot survey revealed the presence of humpback whales in NWHI during the late winter, and several sightings involved whales exhibiting behaviors associated with breeding on wintering grounds (Baker at al. 1984). For example, competitive groups were witnessed (e.g. aggressive charges and collisions amongst animals; underwater exhalations; broadside displays and flipper slapping) and at least 2 sightings included the presence of small calves. In addition, many acoustic detections of humpback whales were made, supplementing the visual detections and providing evidence for humpbacks proximate to shallow banks west of Nihoa, between the shallow regions at Raita Bank and Maro Reef and between Maro Reef and Laysan Island.

While an exhaustive analysis of our acoustic data is beyond the scope of this study, our results reveal the presence of 'singing' whales in the NWHI, another common observation for humpbacks in breeding regions (Au et al. 2000), although not exclusive to breeding habitats (Clapham \& Mattila 1990). All of our humpback whale visual observations were made in shallow regions, at or within the $200 \mathrm{~m}$ isobath despite considerable survey effort in deeper areas. Despite considerable visual and acoustic survey effort at Ladd Seamount (Fig. 1; I), we did not detect humpbacks in this shallow, cool region. Ladd Seamount is a guyot with an extensive summit plateau ranging from 80 to $160 \mathrm{~m}$ and is located approximately $100 \mathrm{~km}$ north of both the average and synoptic $21.1^{\circ} \mathrm{C}$ SST contours. Despite their extensive shallow habitat in the NWHI in general, humpbacks may not have been using this region due to their preference for higher temperature waters. Midway Atoll and Pearl and Hermes Reef were 
also above the synoptic and average $21.1^{\circ} \mathrm{C}$ SST isotherm and no humpbacks were visually detected, although survey effort was extremely limited in that region. Moreover, no humpbacks were detected visually in deep waters warmer than $21.1^{\circ} \mathrm{C}$, despite considerable effort in that habitat (Table 1).

Our observations are consistent with the distribution patterns of wintering humpbacks in other parts of Hawai'i (Herman et al. 1980, Mobley et al. 1999, Craig \& Herman 2000, Mobley et al. 2001), and conform to the patterns seen worldwide for humpback wintering regions (Rasmussen et al. 2007). Considering this, our results suggest that the NWHI should now be considered wintering habitat for humpback whales in the North Pacific. Previous boat-based surveys in this area during November 1975 found no humpback whales (Herman \& Antinoja 1977) nor did 9 Coast Guard flights over the region in the winters of 1976 and 1977 (Shallenberger 1977), although the effort levels for these surveys within appropriate breeding habitat is not well documented. There are also no records of humpback whales in the NWHI-specific issues of the Smithsonian's Atoll Research Bulletin, several issues of which compile historical details on the natural history of much of the region (Binion Amerson 1971, Clapp 1972, Eli \& Clapp 1973, Binion Amerson et al. 1974, Clapp \& Wirtz 1975, Clapp \& Kridler 1977, Clapp et al. 1977). Historical whaling catch evidence suggests that humpback whales did not utilize habitat surrounding the MHI (and presumably the NWHI) until approximately 200 yr ago (Herman 1979).

However, humpback whales have been reported near Midway Atoll during the winter (Nishiwaki 1972), and there are other examples of their presence in the NWHI. Although Herman et al. (1980) discounted them as 'stragglers,' a mother and calf $(<1 / 3$ the length of the mother) were seen off French Frigate Shoals in February 1977. In addition, biologists at French Frigate Shoals reported seeing a group of humpback whales, including one mother/calf pair, within the Atoll (between Tern Island and La Perouse Pinnacle) during the winter of 2003 (J. Sprague pers. comm.).

Two humpback whales were sighted in the 'eastern portion' of the NWHI during December 1976 (Herman \& Antinoja 1977). These animals were reported moving southeasterly, and from these observations (and the lack of other sightings) Herman \& Antinoja (1977) hypothesized that the NWHI may be a migratory route for humpback whales. While this migratory corridor hypothesis has not been rigorously tested, our results indicate that some humpback whales are likely wintering in the NWHI. Humpbacks sometimes exhibit breeding behaviors during migrations (Brown \& Corkeron 1995) and humpback whales are also known to sing during migrations (Clapham \& Mattila 1990).
However, the movements of migrating humpbacks are not generally restricted to shallow habitats such as those occupied during breeding periods. In our pilot study, humpbacks were only detected visually in the shallow regions of the NWHI archipelago (despite similar survey effort in deeper habitat; see Table 1), suggesting that they may be wintering in this region and not using it merely as a migratory corridor. Both Herman (1979) and Herman et al. (1980) found no evidence of humpback migration through the NWHI.

This hypothesis is further supported by recently published satellite telemetry data for humpbacks tagged during 1995 through 2000 on the wintering grounds in Hawai'i and tracked during northward migrations (Mate et al. 2007). While the sample size of tagged whales is low ( $<15$ individuals tracked beyond the Hawaiian EEZ), not one of the tagged whales moved northwest across the NWHI on their journey to northern feeding grounds (although one individual moved southwest below the archipelago towards Johnston Atoll), and the majority of whales moved directly north or northeast towards the coastline of North America after leaving Hawai'i (Mate et al. 2007). One whale tagged in Hawai'i moved north to the Aleutian Islands and only then turned back westward to reach a feeding ground south of the Kamchatka Peninsula (Mate et al. 2007). Further research is required to establish the extent to which whales use the NWHI as wintering habitat.

The amount of shallow, warm-water habitat in the NWHI (approximately $14700 \mathrm{~km}^{2}$ ) appears to be almost double that available in the MHI (approximately $7200 \mathrm{~km}^{2}$ ), and our visual and acoustic observations suggest that humpback whales indeed use portions of this remote region as wintering habitat. This is an important discovery in terms of recovery efforts for North Pacific humpback whales. Until the present, the MHI were considered the only wintering habitat for humpbacks in Hawai'i, and in this region they are subject to considerable interactions with humans, including harmful interactions such as ship strikes (Lammers et al. 2003). The wintering habitat identified in the present study is largely unaffected by humans in this manner, and protections for NWHI fauna have been recently reinforced by the designation of the NWHI as the Papahānaumokuākea Marine National Monument (Anonymous 2006). This designation places significant restrictions on human activities within Monument waters. For example, there is currently little fishing within the Monument, and all fishing will likely be phased out by June 2011 (Anonymous 2006). This provides protection for humpbacks in the NWHI from entanglement locally in active fishing gear, although some animals remain at risk of entanglement in marine debris found throughout the NWHI (D. K. Mattila \& E. 
Lyman unpubl. data). Most humpbacks appear to become entangled in active fishing gear on the feeding grounds (NMFS 1991), although they do occasionally interact with active gear in southern portions of the central North Pacific (Angliss \& Outlaw 2005).

The results of the present study also pose a series of interesting questions regarding efforts to study the population structure and abundance of humpbacks in Hawai'i and may further document their recovery in the North Pacific. Humpback whales may have consistently used the NWHI to over-winter (and remained undetected simply because survey effort was lacking), or our results may indicate an expansion of their wintering range as the population recovers; they may have only recently colonized or re-colonized this more 'remote' habitat, possibly to avoid over-crowding or competition in the MHI. It appears that humpbacks have expanded their distribution in the MHI over time. For example, Mobley et al. (1999) suggested that the significant increase in numbers of humpbacks distributed around Kaua'i and Ni'ihau over a $10 \mathrm{yr}$ period (1980 to 1990) may have resulted from whales 'spilling over' from the 4 islands region (Maui, Lana'i, Moloka'i, Kaho'olawe). The results of the present study indicate that this expansion may now include the NWHI. Considering the central spatial location of the NWHI in the North Pacific, it is possible that this region may host wintering humpback whales that forage in the western North Pacific and as a result may have facilitated documented movements between wintering areas in Japan and Hawai'i between years (Darling \& Cerchio 1993, Salden et al. 1999).

In addition, our results may have great relevance for the current abundance estimates for humpbacks in the North Pacific, and for ongoing research efforts to refine these estimates. Currently, the abundance estimates for Hawaiian humpbacks rely on surveys/data that were collected only in the MHI (Calambokidis et al. 1997, 2001, Mobley et al. 2001) and do not explicitly account for whales using other habitat in the Hawaiian Archipelago. While we did not detect large numbers of whales during our survey, it should be noted that our effort was limited due to time constrictions and we could not sample all deep and shallow habitats in the NWHI. Indeed, the locations of several of our acoustic detections suggest that humpbacks may have been present in shallow locations not directly sampled by our visual surveys. Future efforts to quantify the abundance of humpbacks wintering in Hawai'i using boatbased and aerial line transect surveys or photo-identification mark/recapture techniques may need to account for whales using these more remote habitats. Similarly, other portions of the Pacific Islands Region (PIR) may also be humpback wintering habitat. For example, there are anecdotal reports of humpbacks near Johnston Atoll during the winter months, but recent surveys during March 2006 did not detect any humpback whales (D. W. Johnston unpubl. data). Future cruises to the NWHI during the period of peak density for humpbacks in Hawai'i (Au et al. 2000), and surveys in other portions of the PIR, are required to fully assess the stock structure and abundance of whales wintering in the central Pacific. Furthermore, our simple habitat model, which employs readily available bathymetry and SST data, may be valuable for predicting and identifying potential humpback whale wintering sites in this and other locations, and to guide subsequent visual/acoustic surveys to assess their populations.

Predictive habitat models are extremely valuable for studying cetacean populations, including refining and guiding visual surveys to estimate their abundance (Redfern et al. 2006) through line transect/distance sampling methods (Buckland et al. 2001) or photoidentification/mark-recapture studies (Hammond 1990). Ship time for visual surveys is expensive and difficult to obtain, so methods that identify important areas a priori can help optimize effort allocation across a large study region. In addition, line transect surveys to estimate the abundance of cetaceans usually produce estimates with smaller CVs if information about the distribution of whales is used to help develop a stratified survey design (Buckland et al. 2004). In these situations, regions known to exhibit higher densities are allocated more survey effort than regions with lower densities (Buckland et al. 2004). Considering our results, future line transect surveys to estimate the abundance of humpbacks in the NWHI should employ a stratified survey design that focuses effort in predicted wintering habitat regions along with some coverage in regions outside these high-density habitats.

These methods are also useful for assessing humpbacks on the breeding grounds in other regions. For example, there are indications that some present-day wintering habitats in the North Atlantic remain unidentified (Smith et al. 1999, Charif et al. 2001) and the same is almost certainly true for vast portions of the central Pacific Ocean (e.g. the Marshall Islands Region) and the Indian Ocean. In these areas, the extent and location of wintering habitats could be predicted with a simple spatial model and then assessed with a pilot survey and subsequent complete assessment employing conventional distance sampling/line transect survey methods.

Acknowledgements. Jason Baker, Chad Yoshinaga, Lesley Thorne and Elaine Stuart provided significant help during visual and acoustic surveys. Thanks to Lucas Moxey for providing SST grids for the spatial analysis. Thanks to Amanda Cummins and Mark Deakos for the initial fluke match. This manuscript was improved with comments from: Bud Antonelis, 
Adam Pack, Charles Littnan, Jason Baker, Kerry Irish and 2 anonymous reviewers. This work was conducted under US Federal ESA/MMPA permit 774-1414-03, State of Hawai'i Northwestern Hawaiian Islands State Marine Refuge Permit DLNR/ NWHI/07002 and Papahānaumokuākea Marine National Monument Permit PMNM-2007-008. All research conducted conformed to University of Hawai'i IACUC regulations.

\section{LITERATURE CITED}

Angliss RP, Outlaw RB (2005) Alaska marine mammal stock assessments, 2005. US Department of Commerce, NOAA Technical Memorandum NMFSAFSC-161

Anonymous (2006) Establishment of the Northwestern Hawaiian Islands Marine National Monument. A Proclamation by the President of the United States of America. Office of the Press Secretary, Washington, DC, June 15, 2006

Au WWL, Mobley J, Burgess WC, Lammers MO, Nachtigall PE (2000) Seasonal and diurnal trends of chorusing humpback whales wintering in waters off western Maui. Mar Mamm Sci 16:530-544

Baker CS, Herman LM (1984) Aggressive behavior between humpback whales (Megaptera novaeangliae) wintering in Hawaiian waters. Can J Zool 62:1922-1937

Baker CS, Herman LM, Perry A, Lawton WS and 7 others (1986) Migratory movement and population structure of humpback whales Megaptera novaeangliae in the central and eastern North Pacific. Mar Ecol Prog Ser 31:105-119

Barlow J (2006) Cetacean abundance in Hawaiian waters estimated from a summer/fall survey in 2002. Mar Mamm Sci 22:446-464

Binion Amerson A Jr (1971) The natural history of French Frigate Shoals, Northwestern Hawaiian Islands. Atoll Res Bull 150:1-400

Binion Amerson A Jr, Clapp RB, Wirtz II WO (1974) The natural history of Pearl and Hermes Reef, Northwestern Hawaiian Islands. Atoll Res Bull 174:1-347

Brown MR, Corkeron PJ (1995) Pod characteristics of migrating humpback whales (Megaptera novaeangliae), migrating off Point Lookout, Queensland. Behaviour 132:163-179

Buckland ST, Anderson DR, Burnham KP, Laake JL, Borchers DL, Thomas L (2001) Introduction to distance sampling: estimating abundance of biological populations. Oxford University Press, Oxford

Buckland ST, Anderson DR, Burnham KP, Laake JL, Borchers DL, Thomas L (2004) Advanced distance sampling: estimating abundance of animal populations. Oxford University Press, Oxford

Calambokidis J, Steiger GH, Straley JM, Quinn T and 19 others (1997) Abundance and population structure of humpback whales in the North Pacific basin. Final Contract Report 50ABNF500113, Southwest Fisheries Science Center, La Jolla, CA

Calambokidis J, Steiger GH, Straley JM, Herman LM and 19 others (2001) Movements and population structure of humpback whales in the North Pacific. Mar Mamm Sci 17:769-794

Charif RA, Clapham PJ, Clark CW (2001) Acoustic detections of singing humpback whales in deep waters off the British Isles. Mar Mamm Sci 17:751-768

Chittleborough RG (1965) Dynamics of two populations of the humpback whale, Megaptera novaeangliae (Borowski). Aust J Mar Freshw Res 16:33-128

Clapham PJ, Mattila DK (1990) Humpback whale songs as indicators of migration routes. Mar Mamm Sci 6:155-160 Clapham PJ, Mead JG (1999) Megaptera novaeangliae. Mamm Species 604:1-9

Clapp RB (1972) The natural history of Gardner Pinnacles, Northwestern Hawaiian Islands. Atoll Res Bull 163:1-32

Clapp RB, Kridler E (1977) The natural history of Necker Island, Northwestern Hawaiian Islands. Atoll Res Bull 206: $1-107$

Clapp RB, Wirtz WO II (1975) The natural history of Lisianski Island, Northwestern Hawaiian Islands. Atoll Res Bull 186: $1-209$

Clapp RB, Kridler E, Fleet RR (1977) The natural history of Nihoa, Northwestern Hawaiian Islands. Atoll Research Bull 207:1-154

Craig AS, Herman LM (2000) Habitat preferences of female humpback whales Megaptera novaeangliae in the Hawaiian Islands are associated with reproductive status. Mar Ecol Prog Ser 193:209-216

Darling JD, Cerchio S (1993) Movement of a humpback whale (Megaptera novaengliae) between Japan and Hawaii. Mar Mamm Sci 9:84-89

Dawbin WH (1966) The seasonal migratory cycle of humpback whales. In: Norris KR (ed) Whales, dolphins and porpoises. University of California Press, Berkeley, CA, p 145-170

Eli CA, Clapp RB (1973) The natural history of Laysan Island, Northwestern Hawaiian Islands. Atoll Res Bull 171:1-373

Ersts PJ, Rosenbaum HC (2003) Habitat preference reflects social organization of humpback whales (Megaptera novaeangliae) on a wintering ground. J Zool 260:337-345

Hammond PS (1990) Capturing whales on film - estimating cetacean population parameters from individual recognition data. Mamm Rev 20:17-22

Herman LM (1979) Humpback whales in Hawaiian waters: a study in historical ecology. Pac Sci 33:1-15

Herman LM, Antinoja RC (1977) Humpback whales in the Hawaiian breeding water: population and pod characteristics. Sci Rep Whales Res Inst Tokyo 29:59-85

Herman LM, Hancock JM, Forestell PH, Antinoja RC (1980) The 1976/77 migration of humpback whales into Hawaiian waters: composite description. Marine Mammal Commission Report MMC-77/19, Marine Mammal Commission, Washington, DC

Johnson JH, Wolman AA (1984) The humpback whale, Megaptera novaeangliae. Mar Fish Rev 46:30-37

Karczmarski L, Wursig B, Gailey G, Larson KW, Vanderlip C (2005) Spinner dolphins in a remote Hawaiian atoll: social grouping and population structure. Behav Ecol 16: 675-685

Katona SK, Beard JA (1990) Population size, migrations, and feeding aggregations of the humpback whale (Megaptera novaeangliae) in the western North Atlantic Ocean. Rep Int Whal Comm Spec Issue 12:295-305

Lammers MO, Pack AA, Davis L (2003) Historical evidence of whale/vessel collisions in Hawaiian waters (1975-present). OSI Technical Report 2003-01. Prepared for the Hawaiian Islands Humpback Whale National Marine Sanctuary. Oceanwide Science Institute, Honolulu, HI

Mate B, Mesecar R, Lagerquist B (2007) The evolution of satellite-monitored radio tags for large whales: one laboratory's experience. Deep-Sea Res II 54:224-247

Mizroch SA, Herman LM, Straley JM, Glockner-Ferrari DA and 6 others (2004) Estimating the adult survival rate of central North Pacific humpback whales (Megaptera novaeangliae). J Mammal 85:963-972

Mobley JR, Bauer GB, Herman LM (1999) Changes over a ten-year interval in the distribution and relative abun- 
dance of humpback whales (Megaptera novaeangliae) wintering in Hawai'i. Aquat Mamm 25:63-72

Mobley JR, Spitz S, Grotefendt R, Forestell P, Frankel A, Bauer G (2001) Abundance of humpback whales in Hawaiian waters: results of 1993-2000 aerial surveys. Report to the Hawaiian Islands Humpback Whale National Marine Sanctuary. Mobley, Spitz, Grotefendt. Marine Mammal Research Consultants, Honolulu, HI

Nishiwaki (1972) General biology. In: Ridgeway SH (ed) Mammals of the sea: biology and medicine. Charles C. Thomas, Springfield, IL, p 812

NMFS (National Marine Fisheries Service) (1991) Recovery plan for the humpback whale (Megaptera novaeangliae). Prepared by the Humpback Whale Recovery Team for the National Marine Fisheries Service, Silver Spring, MD

Perry SL, Demaster DP, Silber GK (1999) The great whales: history and status of six pecies listed as endangered under the US Endangered Species Act of 1973. Mar Fish Rev 61:1-67

Rasmussen K, Palacios DM, Calambokidis J, Saborío MT and 5 others (2007) Southern Hemisphere humpback whales wintering off Central America: insights from water temperature into the longest mammalian migration. Biol Lett 3:302-305

Redfern JV, Ferguson MC, Becker EA, Hyrenbach KD and 15 others (2006) Techniques for cetacean-habitat modeling.

Editorial responsibility: Sascha Hooker,

St. Andrews, UK
Mar Ecol Prog Ser 310:271-295

Rice DW (1978) The humpback whale in the North Pacific: distribution, exploitation, and numbers, Appendix 4. In: Norris KS, Reeves RR (eds) Report on a workshop on problems related to humpback whales (Megaptera novaeangliae) in Hawaii. National Technical Information Service Report PB-280 794. US Department of Commerce, Springfield, VA, p 29-44

Rice DW, Wolman AA (1982) Whale census in the Gulf of Alaska, June to August, 1980. Rep Int Whal Comm 32:491-498

Salden DR, Herman LM, Yamaguchi M, Sato F (1999) Multiple visits of individual humpback whales (Megaptera novaeangliae) between Hawaiian and Japanese winter grounds. Can J Zool 77:504-508

Shallenberger E (1977) Humpback whales in Hawaii: population and distribution. OCEANS 9:738-744

Smith TD, Allen J, Clapham PJ, Hammond PS and 8 others (1999) An ocean-basin-wide mark-recapture study of the North Atlantic humpback whale (Megaptera novaeangliae). Mar Mamm Sci 15:1-32

Whitehead H, Moore MJ (1982) Distribution and movements of West Indian humpback whales in winter. Can J Zool 60:2203-2211

Wolman AA, Jurasz CM (1977) Humpback whales in Hawai'i: vessel census 1976. Mar Fish Rev 39:1-5

Submitted: July 3, 2007; Accepted: August 24, 2007

Proofs received from author(s): September 6, 2007 